\title{
Physiological quality, content and activity of antioxidants in soybean seeds artificially aged ${ }^{1}$
}

\author{
Marizangela Rizzatti Ávila²*, Alessandro de Lucca e Braccini ${ }^{3}$, Cristina Giatti \\ Marques de Souza 3 , José Marcos Gontijo Mandarino ${ }^{4}$, Gabriel Loli Bazo ${ }^{3}$, \\ Yara Camila Fabrin $\mathrm{Cabral}^{5}$
}

\begin{abstract}
The objective of this study was to evaluate physiological quality, content, and activity of antioxidants, in soybean seeds subjected to accelerated aging during different periods. Seeds of cultivars BRS 258, BRS 262 and BRS 268, subjected to accelerated aging during 12, 24, 36 and 48 hours and non-aged seeds were used. After each aging period, the seed were evaluated by tests of: germination; first count and tetrazolium. The total of phenolic compounds, total flavonoides, total of isoflavones, and activity for eliminating $\mathrm{ABTS}^{\bullet+}$ radicals were quantified. There were differences among cultivars according to vigor and viability only after seeds were aged. Cultivars BRS 158 and BRS 268 have shown better seed physiological quality in each aging period; however, not presenting higher amounts of isoflavones and efficiency in removing free radicals. For all cultivars, the values for total of phenolic compounds, as well as total of flavonoids have shown quadratic positive behavior; the values for isoflavones remained constant and the vigor and viability showed contrary trend to activity of antioxidant agents.
\end{abstract}

Index terms: isoflavones, Glycine max, phenolic compounds, viability, vigor.

\section{Qualidade fisiológica, conteúdo e atividade de antioxidantes presentes em sementes de soja envelhecidas artificialmente}

\begin{abstract}
RESUMO - O objetivo deste trabalho foi avaliar a qualidade fisiológica, o conteúdo e a atividade de agentes antioxidantes presentes em sementes de soja envelhecidas durante diferentes períodos. Foram utilizadas sementes das cultivares BRS 258, BRS 262 e BRS 268, envelhecidas durante $12,24,36$ e $48 \mathrm{~h}$ e sementes não envelhecidas. Após cada período de envelhecimento, as sementes foram avaliadas pelo testes de: germinação; primeira contagem e tetrazólio. Foram quantificados: compostos fenólicos totais; flavonóides totais; total de isoflavonas e atividade eliminadora do radical $\mathrm{ABTS}^{\bullet+}$. Houve diferença entre as cultivares em relação ao vigor e viabilidade somente quando foram envelhecidas. BRS 158 e BRS 268 apresentaram melhor qualidade fisiológica de sementes em cada período de envelhecimento, porém, não apresentaram maior quantidade de isoflavonas e eficiência no sequestro dos radicais livres. Para todas as cultivares, os valores de compostos fenólicos totais, assim como os flavonóides totais, apresentaram comportamento quadrático positivo; os valores das isoflavonas permaneceram constantes e o vigor e a viabilidade apresentaram tendência contrária à atividade dos agentes antioxidantes.
\end{abstract}

Termos para indexação: isoflavonas, Glycine max, compostos fenólicos, viabilidade, vigor.

${ }^{1}$ Submitted on 07/11/2011. Accepted for publication on 01/16/2012.

${ }^{2}$ Instituto Agronômico do Paraná, Caixa Postal 482, 86001-910-Londrina, PR, Brasil.

${ }^{3}$ Universidade Estadual de Maringá, 87020-900-Maringá, PR, Brasil.
${ }^{4}$ Embrapa Soja, Caixa Postal 231, 96001-970-Londrina, PR, Brasil.

${ }^{5}$ Departamento de Ciências Agronômicas, Universidade Estadual de Maringá, 87507-190-Umuarama, PR, Brasil.

*Corresponding author $<$ marizangela_rizzatti@hotmail.com> 


\section{Introduction}

Because of its importance, and within the productive process of the soybean crop, the use of high physiological quality seeds is essential, since it is in the field that one actually recognizes their capacity in producing high vigor seedlings.

Notwithstanding, the maintenance of such quality during the production and storage processes requires technical improvement aiming at softening the deteriorative process, which Delouche (1982) has defined as inexorable and irreversible.

The deterioration process occurs mainly as consequence of the respiratory process, where oxidation and consequent formation of free radicals occur (Marcos-Filho, 2005).

In the cells that compose soybean seeds, such free radicals may cause changes, acting mainly on the fatty acids, causing peroxidation of lipids; what affects structural and functional integrity of cellular membrane, altering its fluidity and permeability, besides provoking inactivation of nucleic acids degradation enzymes (Marcos-Filho, 2005). According to Priestley and Leopold (1983), soybean seeds are especially vulnerable to attack of free radicals, because their chemical composition is rich in lipids and such factor has been appointed as one of the main mechanisms involved in the seed deterioration process.

There are conflicting arguments, however, on the affirmation that the degenerative process is irreversible. For Coolbear (1995), under given conditions and levels of deterioration, there is possibility that self-repairing mechanisms come into action; in this case, some groups of phenolic compounds could act, emphasizing the isoflavonoids and mainly the isoflavones, which present themselves as of important use (Taiz and Zeiger, 2004).

Some isoflavones have antioxidant action (Esaki et al., 1998; Shahidi and Wanasundara, 1992), a fact that may be correlated to protection of cells that compose seeds against action of free radicals; thus diminishing deterioration effects and consequently aiding on maintenance of seed physiological quality.

This manner, the presence of isoflavones in chemical composition of soybean seeds may have relation with the antioxidant protection of these compounds. Up to the moment, it is known that the content of isoflavones on soybean seeds is influenced by the interaction of genotype $\mathrm{x}$ environment, i.e., genetics $x$ local in which the plants were cultivated (CarrãoPanizzi et al., 2003; Ávila et al., 2007), as well as on period of storage of a determined soybean cultivar (Ávila et al. 2011); besides that their content seems to be correlated with the physiological quality of seeds (Ávila et al., 2007).

Studies related to identification; quantification and activity of antioxidant agents in soybean seeds (phenolic compounds, flavonoids, and isoflavones), during deterioration process, were not found in the literature, up to the moment. This way, the objective of this study was to assess physiological quality, the content and the activity of antioxidant agents present on soybean seeds during different time periods of aging.

\section{Material and Methods}

The experimental work was carried out in the Laboratory of Seeds Technology, of the Nucleus for Research Applied to Agriculture; Laboratory of Biochemistry and Physiology of Microorganisms, of the State University of Maringá; and in the Laboratory of Physic-chemical Analyses, of Embrapa-Soybean.

A completely randomized experimental design was used, with the treatments arranged into a $3 \times 5$ factorial scheme (3 soybean cultivars: BRS 258, BRS 262 and BRS $268 \times 5$ accelerated aging periods: 0, 12, 24, 36 and $48 \mathrm{~h}$ ), without interruption in time during seed aging.

The seeds were aged into Water Jacket Chamber (brand Scientific VWR, model 3015). The accelerated aging test was carried out with six replications of 50 seeds each, for each cultivar, which were evenly arranged, in a single layer, on top of a stainless screen inserted on the upper edge of $11 \mathrm{~cm} \times 11 \mathrm{~cm} \times 3.5 \mathrm{~cm}$ germination boxes (gerbox), containing $40 \mathrm{~mL}$ of distilled water and kept under constant temperature of $41{ }^{\circ} \mathrm{C}$, according to recommendations available in the literature (Hampton and Tekrony, 1995; Marcos-Filho, 1999). After each aging period, the seeds were subjected to the following tests:

First count of germination: this test was performed with eight subsamples of 50 seeds each, for each replication. For this, seeds were evenly placed on top of two sheets of germination paper, covered with another sheet of the same paper, which had been moistened with distilled water, at a ratio of 2.5 times de mass of dry substrate. After sowing, the set (paper + seeds) were made into rolls, and placed into a Mangelsdorf type seed germinator, at $25 \pm 1{ }^{\circ} \mathrm{C}$. The assessment was performed at the fifth day after test beginning, according to criteria established by the Rules for Seed Testing (RST) (Brasil, 2009).

Tetrazolium test: was performed with eight replications of 50 seeds each, for each replication. For this test, seeds were preconditioned into sheets of germination paper 
moistened with distilled water, at an amount sufficient to cause seed imbibition, placed into a BOD type incubator, at $25{ }^{\circ} \mathrm{C}$, during $16 \mathrm{~h}$. After such period, the seeds were submerged into a $0.075 \%$ tetrazolium solution $(2,3,5$ triphenyl tetrazolium chloride) and kept into BOD type incubator, at $40{ }^{\circ} \mathrm{C}$, for $3 \mathrm{~h}$, in the dark. After the staining procedure, the seeds were washed and kept submerged in water until the evaluation moment. Seeds were then assessed individually by longitudinally and symmetrically sectioning them through the embryonic axis, with the aid of a razor blade, and sorted according to criteria proposed by (FrançaNeto et al., 1999). Viability (classes 1 to 5) was represented by the proportion of seeds belonging to each class, and the level of vigor (classes 1 to 3). Potential of vigor and viability were expressed in percentage (França-Neto et al., 1999).

In preparing samples for assessment of the content and of the action of antioxidant agents, the soybean seeds, from each treatment, were ground with the aid of a blade mill, at 17,000 rpm, during 1 min., thus obtaining a meal with particles of $0.5 \mathrm{~mm}$ diameter. Afterwards, $15 \mathrm{~g}$ of such meal were placed into $250 \mathrm{~mL}$ capacity Erlenmeyer flasks, into where $50 \mathrm{~mL}$ of hexane were then added. The mixture remained under constant shaking, onto a shaker at $80 \mathrm{rpm}$ speed, during $24 \mathrm{~h}$, at room temperature. Ending that time, the samples were filtrated with the aid of: vacuum filter, lined with no.1 Watman filter paper; Büchner funnel; and a Kitassato flask, which has collected the solvent excess. The defatted meal remained in the filter paper, at room temperature, during more $12 \mathrm{~h}$, for allowing total evaporation of hexane; and starting from this procedure, the extract preparation was initiated.

For extraction, the methodology proposed by CarrãoPanizzi et al. (2002) was used, with modifications according to the proportion of solution used. For such, $5 \mathrm{~g}$ of defatted soybean meal were placed into screw cap test tubes, which then received $15 \mathrm{~mL}$ of extraction solution, composed of ethanol $70 \%$ and $0.1 \%$ acetic acid. The test tubes remained for $1 \mathrm{~h}$ at room temperature, being vigorously shaken at each 15 min., onto a Vortex type test tube shaker. Afterwards, the content of these test tubes was again filtered, and the solution was centrifuged during $14 \mathrm{~min}$., at 14,000 rpm and then exposed to sonication in ultrasound, during $30 \mathrm{~min}$., at room temperature.

Total phenolic compounds: the total of soluble phenolic compounds, present in the extract, was quantified by the Folin Ciocalteu method, according to what was described by Singleton and Rossi (1965). Such method is based on reduction of the phosphomolybdic- phosphotugstic acid by phenolic hydroxyls, producing a blue complex (a mixture of the blue oxides of tungsten), which can be read in spectrophotometer.

The samples were prepared by the transference of a $2 \mathrm{~mL}$ aliquot of the extract to a $10 \mathrm{~mL}$ capacity test tube containing $0.3 \mathrm{~mL}$ of $\mathrm{Na}_{2} \mathrm{CO}_{3}$ (sodium carbonate) at $1.9 \mathrm{M}$, and $0.1 \mathrm{~mL}$ of Folin's reagent $2 \mathrm{~N}$ (1:2 dilution).

The samples remained during $1 \mathrm{~h}$ in dark environment and then the absorbance was read at $725 \mathrm{~nm}$, by using plastic cuvettes in a spectrophotometer, Micronal brand, Model B380.

To zeroing the apparatus a blank solution, composed of distilled water $(2 \mathrm{~mL})$ plus the remaining reagents $(0.3 \mathrm{~mL}$ of $\mathrm{Na}_{2} \mathrm{CO}_{3}$ at $1.9 \mathrm{M}$ and $0.1 \mathrm{~mL}$ of $1 \mathrm{~N}$ Folin's reagent) was used.

Content of total phenolic compounds was determined by interpolation of the absorbance of samples against the calibration curve built with catechin $(2,4,6,8$, and $10 \mu \mathrm{g} \mathrm{mL}^{-1}$ ). The equation of catechin calibration curve was $\mathrm{y}=0.06154 \mathrm{x}+0.02262$; where: $\mathrm{y}=$ concentration of catechin; $\mathrm{x}=$ absorbance at $725 \mathrm{~nm}$. Coefficient of correlation $\left(\mathrm{R}^{2}\right)$ was $=0.98$. The result was computed by the equation: TPC $=$ Absorbance $\times$ Fc $\times$ Dilution; where: $\mathrm{TPC}=$ total phenolic compounds, in $\mu \mathrm{g} \cdot \mathrm{ml}^{-1}$, i.e., catechin equivalent per gram of soybean meal; Absorbance $=$ value read in the spectrophotometer; $\mathrm{Cf}=$ Calibration factor, which was equal to 16.24 ( 1 value of the straight line slope $\left.^{-1}\right)$, catechin curve; Dilution of sample $=100$ times. All analyses were performed in triplicate.

Total flavonoids: the methodology of Woiski and Salatino (1998) was used; where, in an aliquot of $0.5 \mathrm{~mL}$ of the extract, were added $0.5 \mathrm{~mL}$ of $\mathrm{AlCl}_{3} \cdot 6 \mathrm{H}_{2} \mathrm{O}$ (aluminum chloride $2 \%$, into methanol) plus $2.5 \mathrm{~mL}$ of ethanol, within $10 \mathrm{~mL}$ capacity test tubes.

Samples remained during $1 \mathrm{~h}$ into dark environment, and afterwards the absorbance was measured, at $420 \mathrm{~nm}$, by using glass cuvettes, having as "blanks" all reagents $[0.5$ $\mathrm{mL}$ of $\mathrm{AlCl}_{3} \cdot 6 \mathrm{H}_{2} \mathrm{O}$ (aluminum chloride $2 \%$, in methanol) plus $2.5 \mathrm{~mL}$ of ethanol and $0.5 \mathrm{~mL}$ methanol], replacing extract of isoflavones.

Content of total flavonoids was determined by interpolation of absorbance of samples against the calibration curve built with quercetin, used as standard. Result was computed by the equation: $\mathrm{Q}=($ Absorbance +0.1134$) * \mathrm{Fc}$; where: $\mathrm{Q}=$ quantity of flavonoids, in $\mathrm{mg} \mathrm{mL}^{-1}$ (quercetin equivalent per gram of soybean meal); $0.1134=$ correction factor for calibration curve; Absorbance $=$ spectrophotometer reading value; and $\mathrm{Cf}=$ calibration factor, which was equal to 120.80 ( 1 .value of the straight line slope $\left.{ }^{-1}\right)$ of quercetin curve. All analyses were performed in triplicate. 
Isoflavones: $2 \mathrm{~mL}$ of isoflavones extracts were filtered through Millipore micro-filter $(0.45 \mu \mathrm{m}$ pore $)$. From the filtered sample, aliquots of $40 \mathrm{~mL}$ were collected and then transferred to auto-injection test tubes of High Performance Liquid Chromatograph (HPLC), Waters brand, model 2690, with automatic injector of samples. It was used a reverse phase column, ODS C18 type (YMC Pack ODS-AM Columm), $250 \mathrm{~mm}$ long x $0.4 \mathrm{~mm}$ internal diameter, and particles of $5 \mu \mathrm{m}$. From each sample, six HPLC analysis replications were performed.

Separation and quantification of isoflavones were performed according to methodology recommended by Berhow (2002). For the separation of isoflavones, a binary linear gradient system was adopted, having as mobile phases: the methanol, with $0.025 \%$ of Trifluoroacetic Acid (TFA), as solvent A; and ultrapure deionized and distilled $\mathrm{H}_{2} \mathrm{O}$, containing $0.025 \% \mathrm{TFA}$, as solvent $\mathrm{B}$. The initial gradient was $20 \%$ for the solvent $\mathrm{A}$; which reached concentration of $100 \%$ in $40 \mathrm{~min}$. and immediately after returned to $20 \%$, in $41 \mathrm{~min}$.; remaining as such until $1 \mathrm{~h}$, what was the total run- time for each sample. The flow of the mobile phase was of $1 \mathrm{~mL} \mathrm{min.}{ }^{-1}$ and the temperature during run was $25^{\circ} \mathrm{C}$.

Detection of isoflavones was performed by using a photo-diode arrangement detector, Waters brand, model 996, adjusted for wavelength total of $260 \mathrm{~nm}$. For detecting the isoflavones, patterns of daidzin, daidzein, genistin and genistein, Sigma brand, solubilized in methanol (HPCL degree), were used in the following concentrations: $0.00625 ; 0.0125 ; 0.0250 ; 0.05$ and $0.1000 \mathrm{mg} \mathrm{mL}^{-1}$. For quantification of the malonyl-coenzymes forms, the external patterns were used as references, as well as the molar extinction coefficient for each one of them. The isoflavones content was computed in $\mathrm{mg} 100 \mathrm{~g}^{-1}$ of soybean meal, and then transformed into percentage, with all analyses triplicately performed.

Eliminatory activity of ABTS + radical cations: the 2,2'-azinobis-(3-ethylbenzothiazoline-6-sulfonate) (ABTS•+) activity was measured according to Re et al. (1999) methodology. The ABST reagent was prepared by mixing $5 \mathrm{~mL}$ of $7 \mathrm{mM}$ of ABTS with $88 \mathrm{~mL}$ of $\mathrm{K}_{2} \mathrm{~S}_{2} \mathrm{O}_{8}$ (potassium persulfate) $140 \mathrm{mM}$. The mixture was maintained in the dark, during $16 \mathrm{~h}$, to allow complete generation of radical. Afterwards, the mixture was diluted with methanol, until the 1.1 absorbance, at $734 \mathrm{~nm}$. To determine the activity of elimination, a $2.850 \mathrm{~mL}$ aliquot of ABTS reagent was mixed with $0.150 \mathrm{~mL}$ of the sample, or of the negative control $\left(\mathrm{H}_{2} \mathrm{O}\right)$. The test tubes remained in the dark and the absorbance (A) was measured at $734 \mathrm{~nm}$, after $2 \mathrm{~h}$. The Butylhydroxytoluene (BHT) $0.2 \%$ was used as positive control. The kidnapping activity was expressed as percentage of kidnap efficiency of free radicals, through equation: $(\%)=(1-$ sample A / control A $) \times 100$. All analyses were performed in triplicate.

Statistical analyses: the ANOVA of data was performed, and the effects of cultivars, within each period of accelerated aging, were compared by Tukey test; while the effects of the accelerated aging periods for each cultivar, were assessed by polynomial regression; with both, at $5 \%$ probability.

\section{Results and Discussion}

Data presented on Figures 1 and 3, referring to the three studied soybean cultivars, in each accelerated aging period, allow comparison of physiological quality of seeds.

On Figure 1, it can be observed that seed vigor of BRS 268 soybean cultivar, assessed by tests of percentage of normal seedlings and first count of germination, was higher than the cultivars BRS 262 and BRS 258, in all accelerated aging periods; except the time zero. The physiological potential of cultivar BRS 262 seeds was equal to cultivar BRS 258, in the accelerated aging periods of 12,24 , and $36 \mathrm{~h}$; except when seeds were aged during $48 \mathrm{~h}$, a period in which seeds of soybean cultivar BRS 262, have presented the lowest vigor.

Such results are explained by the seed deterioration process that has its speed influenced by the genotype, as well as by seed exposure time to adverse environmental factors such as temperature and relative humidity. This occurs in consequence of the increase of metabolism of the seeds for the self-maintenance of life; and the consequent expense of energy in maintaining the defense mechanisms against deterioration process. It is possible to observe that, at zero time, i.e., when the seeds were not yet subjected to stress caused by the accelerated aging process; where no statistically significant difference in seed vigor was observed among the different cultivars.

Through data presented on Figure 2, it is possible to verify that in the zero time, there has been no difference on seed vigor, when these seeds were assessed by the tetrazolium test, and that BRS 268 cultivar seeds have had the largest vigor among all accelerated aging periods, as compared to seeds of the cultivars BRS 262 and BRS 258. 


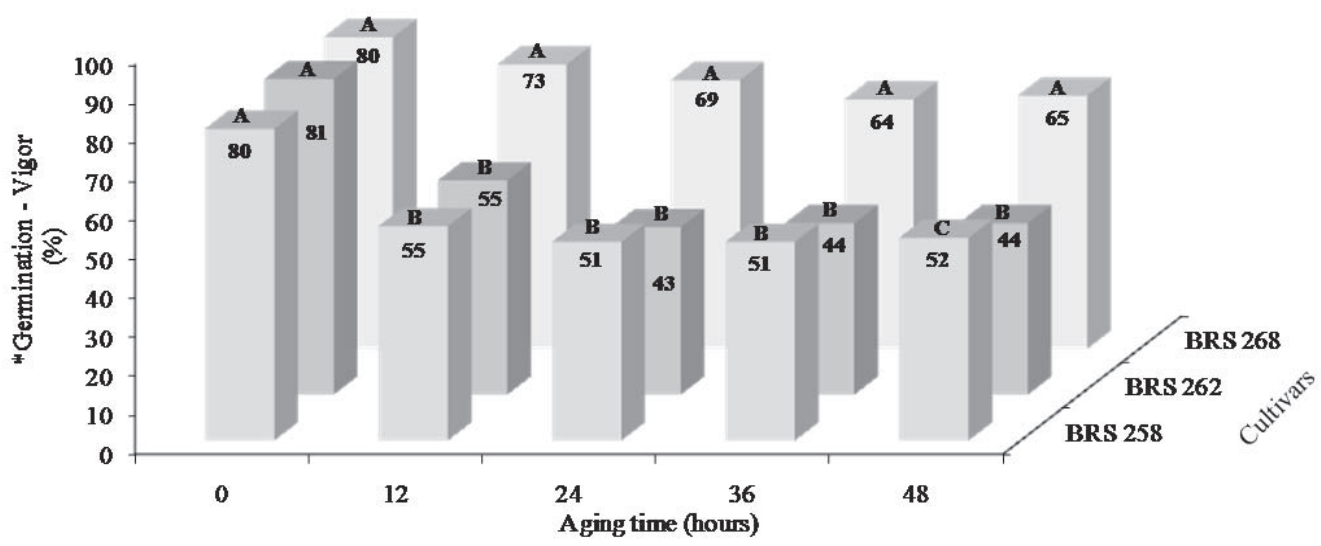

Figure 1. Vigor assessed by the first count of germination test of seeds of three soybean cultivars in each period of accelerated aging.

* Means followed by the same capital letter among columns, compares cultivars in each aging time and are not estatistically different between each other by Tukey test at $5 \%$ probability.

D.M.S. $=7,81 \quad$ C.V. $=9,42$

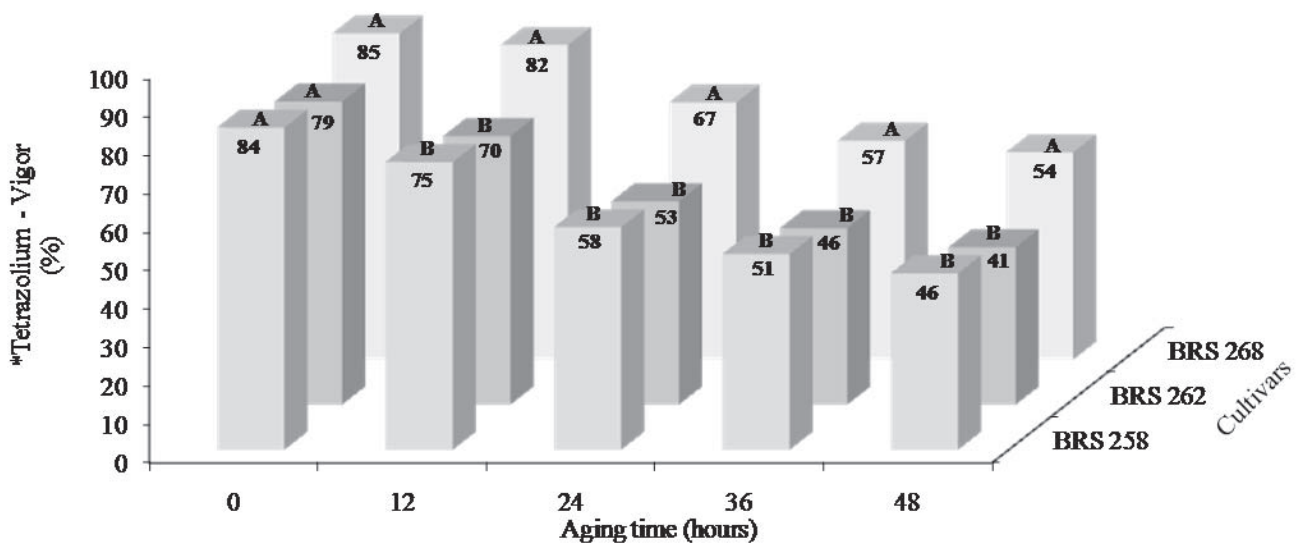

Figure 2. Vigor assessed by the tetrazolium test of seeds of three soybean cultivars within each period of accelerated aging.

* Means followed by the same capital letter among columns, compares cultivars in each aging time and are not estatistically different between each other by Tukey test at $5 \%$ probability.

D.M.S. $=6,22 \quad$ C.V. $=7,07$

In the tetrazolium test, the viability of seeds was the same for the three cultivars within the periods from zero to $12 \mathrm{~h}$ of accelerated aging. During the periods of 24,36 and $48 \mathrm{~h}$, however, the seeds of cultivars BRS 258 and BRS 268 have presented higher viability, as compared to seeds of cultivar BRS 262 (Figure 3).

In a general way, it is possible to observe that seeds from cultivars BRS 258 and BRS 268 were the ones presenting the best physiological quality, within each accelerated aging period.

The content of total phenolic compounds was variable for the three cultivars studied. It was also possible to verify that seeds of cultivar BRS 268, have presented higher amounts of phenolic compounds than the remaining cultivars, in all the accelerated aging periods, except the periods of 12 and $36 \mathrm{~h}$ (Figure 4).

In the evaluation of several classes of phenolic compound present in seeds of 20 soybean cultivars Malencic et al. (2007) have found that high content of total phenols were present in seeds of the Serbian cultivar 1511 and in the Chinese cultivar LN92-7369. The same authors have also found low content of phenols in the Serbian cultivars Tara and Sava. These results indicate that the amount of these compounds is linked to the genotype. 


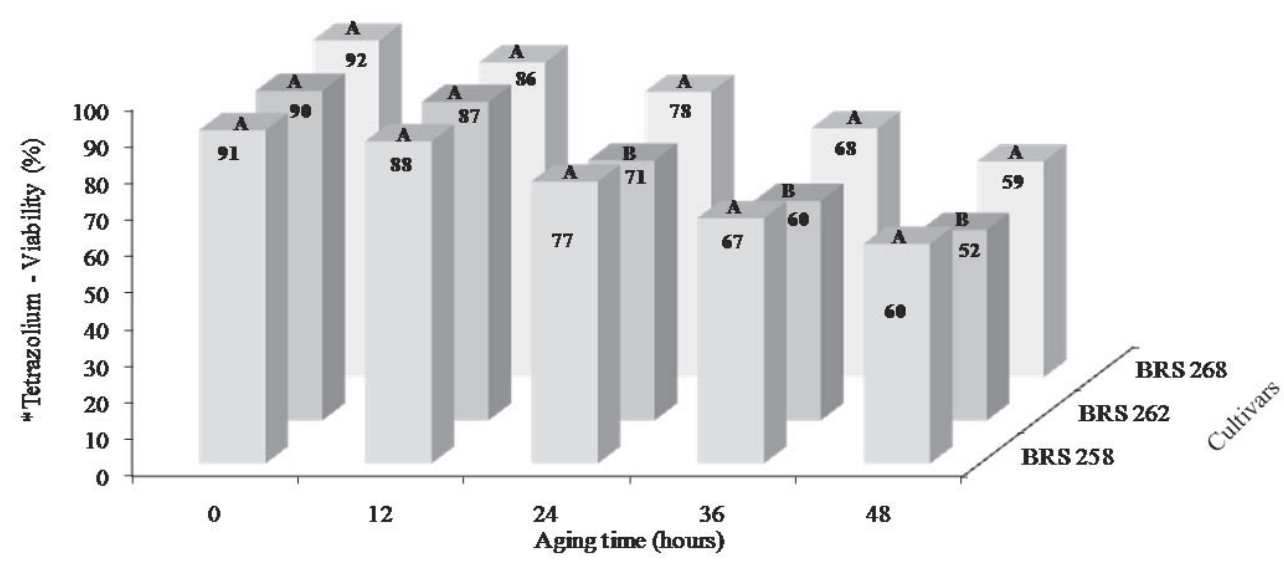

Figure 3. Seed viability assessed by the tetrazolium test in seeds of three soybean cultivars in each period of accelerated aging.

* Means followed by the same capital letter among columns, compares cultivars in each aging time and are not estatistically different between each other by Tukey test at $5 \%$ probability.

D.M.S. $=5,99 \quad$ C.V. $=5,93$

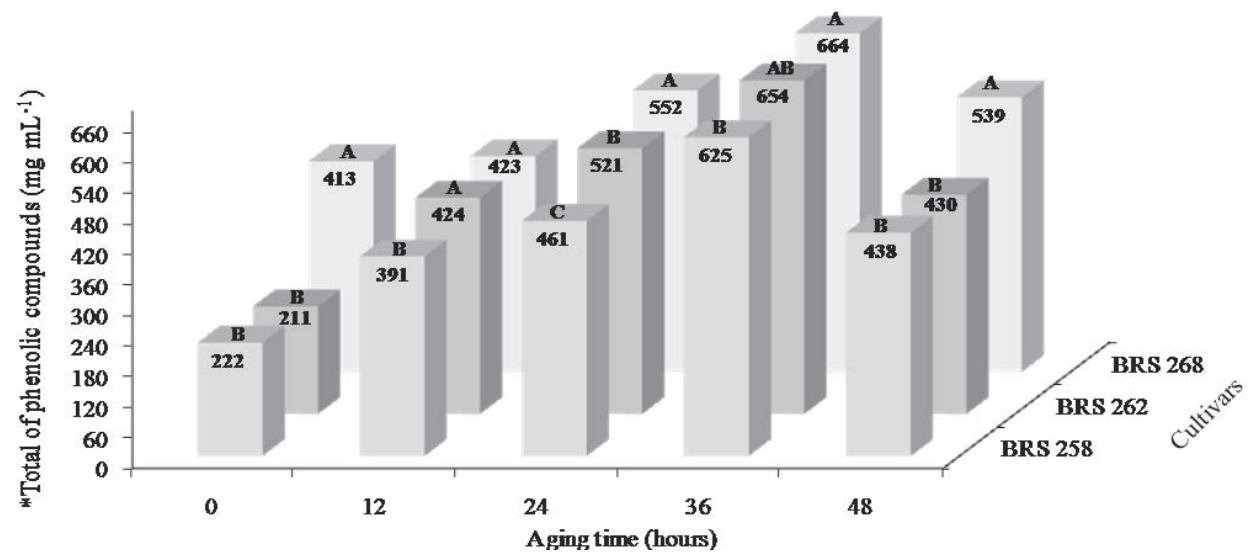

Figure 4. Total of phenolic compounds present in seeds of three soybean cultivars in each period of accelerated aging.

* Means followed by the same capital letter among columns, compares cultivars in each aging time and are not estatistically different between each other by Tukey test at $5 \%$ probability.

D.M.S. $=31,16 \quad$ C.V. $=4,61$

On Figure 5 are presented data on content of total flavonoids in the seeds, which varied among cultivars and among accelerated aging periods; with emphasis on cultivar BRS 268, which presented the highest value for total flavonoids, in relation to cultivars BRS 262 e BRS 258 at 0,12 and $24 \mathrm{~h}$ of accelerated aging. After a period of $36 \mathrm{~h}$ accelerated aging, the amount of these compounds was equal for cultivars BRS 268 and BRS 262; once both presented higher content than the seeds of cultivar BRS 258 . After $48 \mathrm{~h}$ of accelerated aging, however, the content of total flavonoids was equal in seeds of cultivars BRS 258 and BRS 268, and lower in the seeds of cultivar BRS 258 and BRS 268.

On Figure 6 it can be observed that for all accelerated aging periods, seeds of cultivars BRS 268 and BRS 262 presented the same quantities of isoflavones. Cultivar BRS 258 presented lower content of isoflavones in the seeds when compared with cultivars BRS 268 and BRS 262, in all periods of accelerated aging. This fact may be related with the genetic inheritance of this cultivar, once one of its parents is the cultivar BR 36 (Mandarino et al., 2006). This way, it is possible that the difference among content of isoflavones in the seeds of cultivars BRS 268 and BRS 262 , in relation to cultivar BRS 258 is genetic and not a function of a higher or lower tolerance of the cultivars to the accelerated aging process. Several other authors confirm the difference in the content of isoflavones among soybean cultivars (Carrão-Panizzi et al., 2002; CarrãoPanizzi et al., 2003; Ávila et al., 2007; Ávila et al., 2011). 


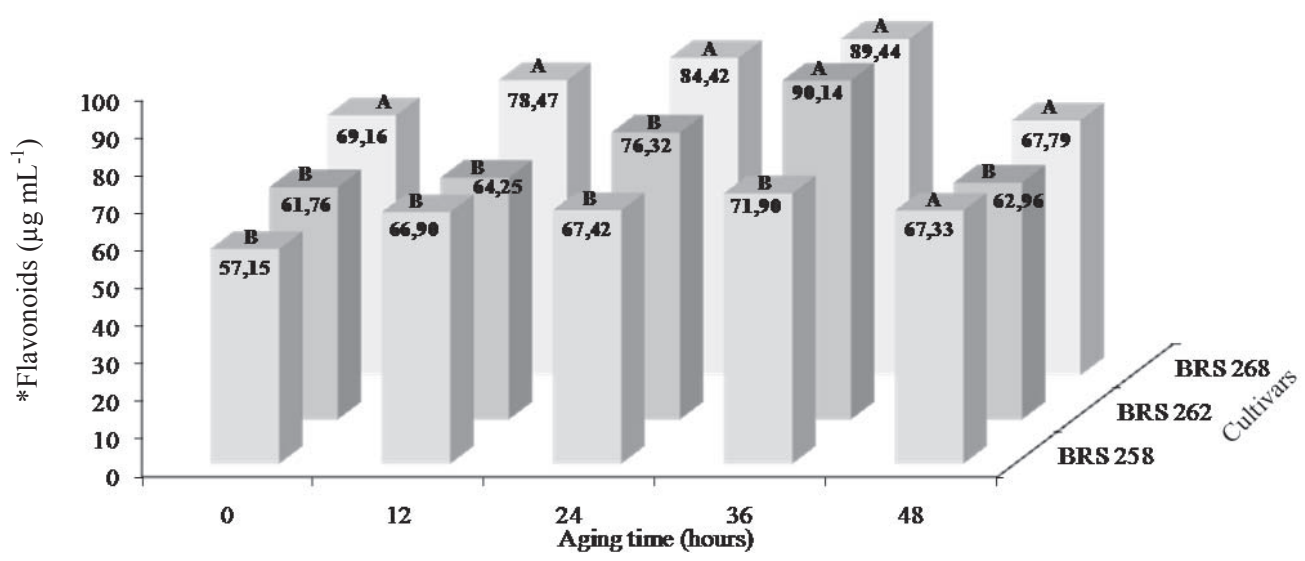

Figure 5. Total flavonoids present in seeds of three soybean cultivars in each period of accelerated aging.

* Means followed by the same capital letter among columns, compares cultivars in each aging time and are not estatistically different between each other by Tukey test at $5 \%$ probability.

D.M.S. $=6,66$ C.V. $=6,87$

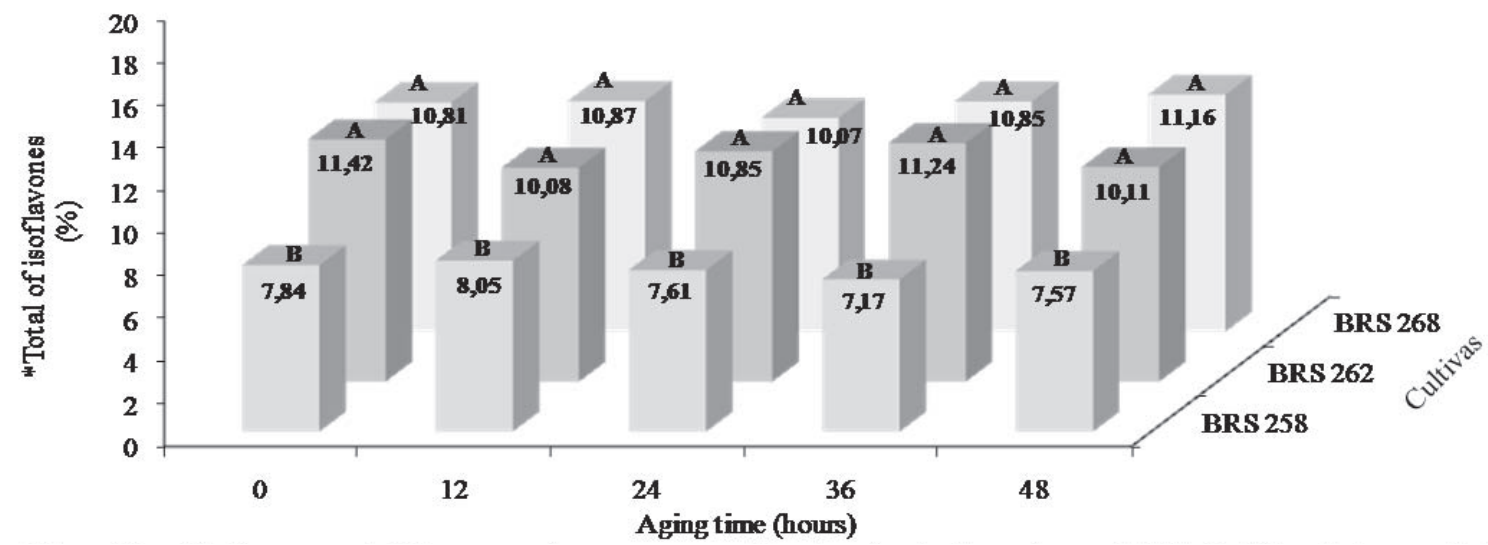

Figure 6. Total of isoflavones present in seeds of three soybean cultivars in each period of accelerated aging.

*Means followed by the same capital letter among columns, compares cultivars in each aging time and are not estatistically different between each other by Tukey test at $5 \%$ probability. Total of isoflavones $(\%)=$ transformed values, arcsen $(\mathrm{x})$.

D.M.S. $=1,10 \quad$ C.V. $=8,11$

Concerning percentage of efficiency in the kidnapping of free radicals (ABTS) (Figure7), before seeds underwent the aging process (time zero) it was observed that the efficiency of kidnapping free radicals from cultivar BRS 268 was equal to that of cultivar BRS 258 and higher than cultivar BRS 262. In relation to the remaining aging periods, it was not possible to differentiate the cultivars concerning such characteristic.

In the assessment of antioxidant capacity of several classes of phenolic compounds in seeds of 20 soybean cultivars, Malencic et al. (2007) found that those cultivars that presented high contents of total phenolic compounds also exhibit higher total antioxidant activity. On the contrary, the genotypes which were poor in phenolic compounds presented low levels of activity in kidnapping free radicals. Such results indicate that the antioxidant capacity of a soybean cultivar may be related to its genetic constitution and not to its physiological quality.

On Table 1 are presented the equations for evaluation of behavior of each cultivar in function of time of accelerated aging, in the results of evaluation of physiological quality of seeds, in the content, and in the activity of antioxidant agents.

The vigor of seeds, observed during the first count of 
germination test, presented a quadratic trend for the seeds of cultivars BRS 258 and BRS 262; it is also possible to verify that the vigor decreased in function of increased time of accelerated aging, presenting the minimum values of $49.89 \%$ e $37.48 \%$ of normal seedlings at the aging periods of $30 \mathrm{~h} 50 \mathrm{~min}$. and $37 \mathrm{~h} 50 \mathrm{~min}$. respectively. The cultivar
BRS 268, however, presented a negative linear trend with an angulation coefficient of -0.32 , i.e., to each hour in which seeds were exposed to aging, there has been a $0.32 \%$ drop on their vigor. Therefore it is observable that the maximum and minimum vigor was $78 \%$ at time zero, and $62.64 \%$ for the $48 \mathrm{~h}$ aging period, respectively.

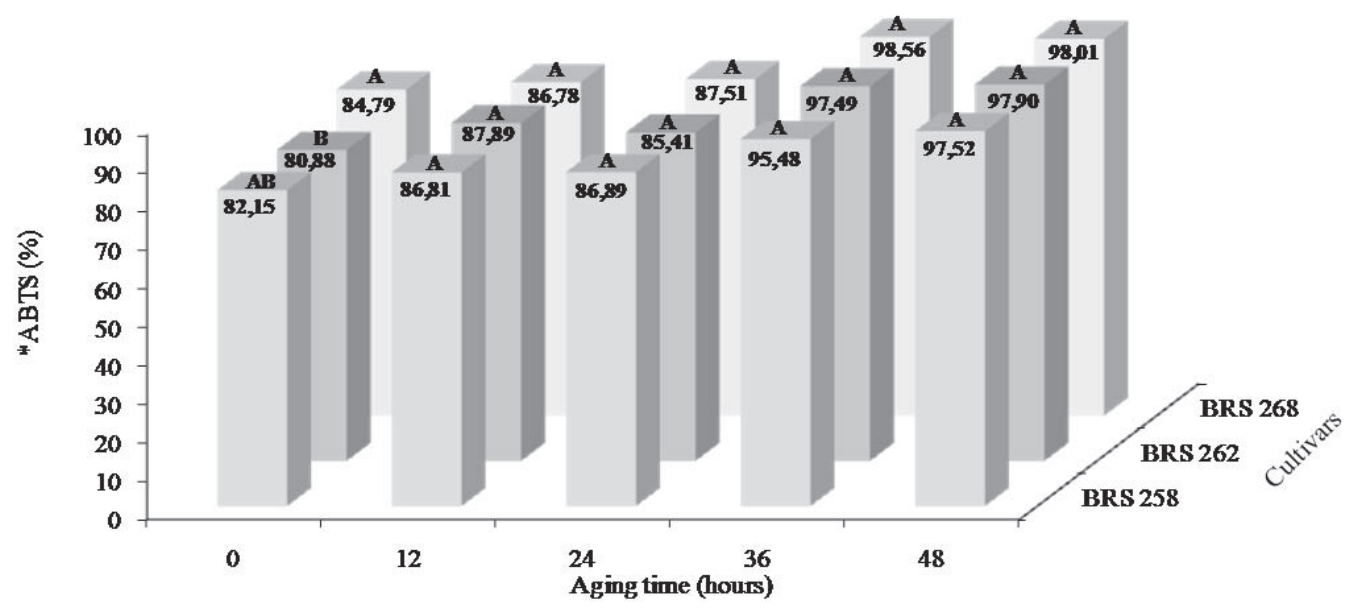

Figure 7. Efficiency of the kidnapping of free radicals present in seeds of three soybean cultivars in each period of accelerated aging.

* Means followed by the same capital letter among columns, compares cultivars in each aging time and are not estatistically different between each other by Tukey test at $5 \%$ probability.

D.M.S. $=3,01$ C.V. $=2,40$

In the tetrazolium test the vigor and viability of seeds were assessed (Table 1). All the studied cultivars presented a decreasing linear trend, i.e., the seeds lost both vigor and viability, while the time of permanence under accelerated aging condition was increased.

For seed vigor, the coefficient of angulation, determined by the first degree equation, allow obtaining values of -0.70 , -0.78 , and -0.88 , respectively for the cultivars already cited, showing a drop in the vigor of $49.60 \%, 38.76 \%$, and $43.96 \%$ after $48 \mathrm{~h}$ exposure to accelerated aging.

For viability of seeds, the coefficient of angulation was $-0.69,-0.84$, and -0.70 . This way it was observed that the viability decreased from $0.69,0.84$, and 0.70 , to each hour in which seeds were exposed to accelerated aging, reaching $58.68 ; 52.48$, and 59.60 at the $48 \mathrm{~h}$ period of accelerated aging.

The drop on germination and vigor is a consequence of the effect provoked by seeds exposure to accelerated aging conditions, which probably caused losses of enzymes, degradation of respiratory system, decrease of ATP production, and cellular membranes disorganization. In addition to loss of cellular compartmentalization, disintegration of membranes system thus impairing metabolism and exchanges of water and solutes between cells and the external environment, and finally determining the total drop of seed viability (Marcos-Filho, 2005).

The reduction on germination capacity and on vigor of seed subjected to accelerated aging is associated to oxidation of lipids and reduction in the synthesis of given proteins, leading to decrease on the content of fatty acids, as well as of the content of phospholipids present in the cell membranes (Stewart and Bewley, 1980; Priestley and Leopold, 1983). Braccini et al. (1999) have found that physiological quality of seeds, of different soybean cultivars; possess a negative linear trend when subjected to increasing exposure periods to accelerated aging; which is in accordance to what was herein found.

It is still observable that for all cultivars assessed; statistically significant differences for total isoflavones in function of accelerated aging time have not occurred. However, the cultivars BRS 258, BRS 262 and BRS 268 , presented median contents of isoflavones of $7.64 \%$, $10.90 \%$ and $10.79 \%$. 
Table 1. Regression equations adjusted to assess the behavior of each one of three soybean cultivar studied, as a function of accelerated aging time.

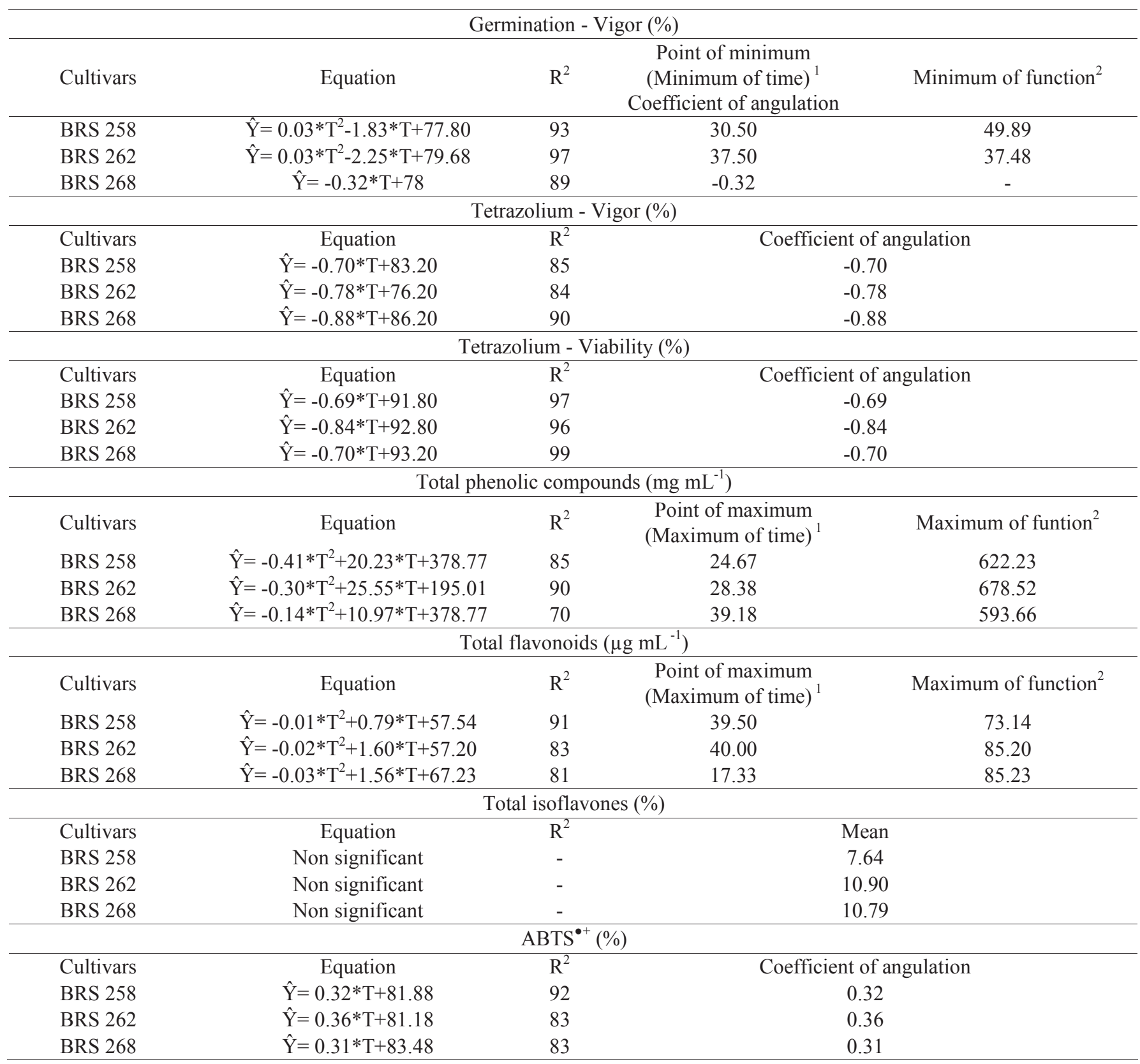

${ }^{1}$ Refers to aging time in which there is no maximum/minimum response, value of $\mathrm{T}$.

${ }^{2}$ Refers to maximum/minimum response corresponding to aging period, value of $Y$.

Although the isoflavones have not presented either increases or decreases in their total content in the $48 \mathrm{~h}$ period of exposure to artificial aging, Ávila et al. (2011) have found that the content of isoflavones may decrease when seeds are stored during six months; but this content is altered only for some cultivars. In this case it has to be considered that changes in the content of isoflavones may be distinct, when seeds are aged naturally of artificially.

It was expected that the quantity of isoflavones would vary due their capacity in avoiding formation of free radicals, by means of inhibition of the reactions that form them; and can also intercept the action of free radicals preventing them to attack the lipids, the amino acids and the nitrogen bases of the DNA of seeds, what is essential 
in the germination process. Besides, being able to repair the damages provoked by the free radicals and to the reconstitution of the already damaged structures.

With reference to content of total phenolic compounds, it is possible to observe that the three cultivars presented a quadratic behavior, i.e., the content of total phenolic compounds was increasing until reaching the maximum percentage of 622.23 $\mathrm{mg} \mathrm{mL} \mathrm{mL}^{-1}, 678.52 \mathrm{mg} \mathrm{mL}^{-1}$ and $593.66 \mathrm{mg} \mathrm{mL}^{-1}$, respectively in the periods of $24.67,28.38$ and $39.18 \mathrm{~h}$ of accelerated aging of seeds and starting from that point, there has been a drop in the content of total phenolic compounds.

The amount of total flavonoids of cultivars studied have increased starting from time zero of aging until a maximum of $73.14 \mu \mathrm{g} \mathrm{mL}^{-1}, 85.20 \mu \mathrm{g} \mathrm{mL}^{-1}$ and $85.23 \mu \mathrm{g} \mathrm{mL}^{-1}$ in the periods of $39.50,40.00$ and $17.33 \mathrm{~h}$; presenting a behavior similar to the content of phenolic compounds.

The three cultivars assessed have presented an increasing linear trend for antioxidant activity, determined by capture of radical ABTS. The coefficient of angulation was of $0.32,0.36$ and 0.31 , i.e., the kidnapping activity increased in $0.32,0.36$, and 0.31 , at each hour in which seeds were exposed to aging, reaching $97.27 \%, 98.46 \%$ and $98.36 \%$, respectively, after $48 \mathrm{~h}$ aging. The increase in the antioxidant activity proves the increase on liberation of free radicals, caused by action of antioxidant agents, probably due to higher respiratory activity of seeds during the period in which these remained exposed to the accelerated aging.

\section{Conclusions}

Seed vigor and viability decreased and the activity of antioxidants in the seeds increases the longer the aging of the seeds. Moreover the amount of isoflavones is not changed.

\section{References}

ÁVILA, M.R.; BRACCINI, A.L.; SCAPIM, C.A.; MANDARINO, J.M.G.; ALBRECHT, L.P.; BAZO, G.L., CABRAL, Y.C.F. Effect of storage period on isoflavone content and physiological quality of conventional and transgenic soybean seeds. Revista Brasileira de Sementes, v.33, n.1, p.149161, 2011. http://www.scielo.br/pdf/rbs/v33n1/17.pdf

ÁVILA, M.R.; BRACCINI, A.L.; SCAPIM, C.A.; MANDARINO, J.M.G.; ALBRECHT, L.P.; FILHO, P.S.V. Componentes do rendimento, teores de isoflavonas, proteínas, óleo e qualidade de sementes de soja. Revista Brasileira de Sementes, v.29, n.3, p.111-127, 2007. http://www. scielo.br/pdf/rbs/v29n3/a14v29n3.pdf

BERHOW, M.A. Modern analytical techniques for flavonoid determination. In: BUSLIG, B.S.; MATHEY, J.A. (Ed.). Flavonoids in the living cell. New York: Klusher Academic, 2002. p.61-76.

BRACCINI, A.L.; REIS, M.S.; SEDIYAMA, C.S.; SCAPIM, C.A.; BRACCINI, M.C.L. Avaliação da qualidade fisiológica de sementes de soja, após o processo de hidratação-desidratação e envelhecimento acelerado. Pesquisa Agropecuária Brasileira, v.34, n.6, p.1053-1066, 1999. http://www.scielo.br/pdf/pab/v34n6/8408.pdf

BRASIL. Ministério da Agricultura, Pecuária e Abastecimento. Regras para análise de sementes. Ministério da Agricultura, Pecuária e Abastecimento. Secretaria de Defesa Agropecuária. Brasília: MAPA/ACS, 2009. 399p. http://www.agricultura.gov.br/arq_editor/file/laborat $\%$ c3\%b3rio/ sementes/regras\%20para\%20analise $\% 20$ de $\% 20$ sementes.pdf

CARRÃO-PANIZZI, M.C.; FAVONI, S.P.G.; KIKUCHI, A. Extraction time for isoflavone determination. Brazilian Archives of Biology and Technology, v.45, n.4, p.515-518, 2002. http://www.scielo.br/pdf/babt/ v45n4/15251.pdf

CARRÃO-PANIZZI, M.C.; SIMÃO, A.S.; KIKUCHI, A. Efeitos de genótipos, ambientes e de tratamentos hidrotérmicos na concentração de isoflavonas agliconas em grãos de soja. Pesquisa Agropecuária Brasileira, v.38, n.8, p.897-902, 2003. http://www.scielo.br/pdf/pab/ v38n8/18229.pdf f

COOLBEAR, P. Mechanisms of seed deterioration; In: BASRA, A.S. (Ed.) Seed quality: Basic mechanisms and agricultural implications. New York: Food Products Press, 1995. p.223-277.

DELOUCHE, J.C. Physiological changes during storage that affect soybean seed quality. In: SINCLAIR, J.B.; JACKOBS, J.A. (Ed.). Soybean seed quality and stand establishment. [S.1.]: Intsoy, 1982. p.5766. (Intsoy, 22).

ESAKI, H.; ONOZAKI, H.; MORIMITSU, Y. Potent antioxidative isoflavones isolated from soybeans fermented with Aspergillus saitoi. Journal of Bioscience, Biotechnology and Biochemistry, v.62, n.4, p.740746, 1998. https://www.jstage.jst.go.jp/article/bbb/62/4/62_4_740/_pdf

FRANÇA-NETO, J.B.; KRZYZANOWSKI, F.C.; COSTA, N.P. Metodologia do teste de tetrazólio em sementes de soja. In: KRZYZANOWSKI, F.C.; VIEIRA, R.D.; FRANÇA-NETO, J.B. (Eds.). Vigor de sementes: conceitos e testes. Londrina: ABRATES, 1999. Cap.8.5, p.1-28.

HAMPTON, J.G.; TEKRONY, D.M. Handbook of vigor test methods. Zürich: ISTA, 1995. 117p.

MALENCIC, D.; POPOVIC, M.; MILADINOVIC, J. Phenolic content and antioxidant properties of soybean (Glycine max L.) seeds. Molecules, n.12, p.576-581, 2007. http://www.mdpi.com/1420-3049/12/3/576/pdf

MANDARINO, J.M.G.; CARRÃO-PANIZZI, M.C.; CRANCIANINOV, W.S. Teor de isoflavonas em cultivares de soja da Embrapa. In: CONGRESSO BRASILEIRO DE SOJA, 4., 2006, Londrina. Resumos... Londrina: Embrapa Soja, 2006. p.132. 
MARCOS-FILHO, J. Fisiologia de sementes de plantas cultivadas. Piracicaba: FEALQ, 2005. 495p.

MARCOS-FILHO, J. Teste de envelhecimento acelerado. In: KRZYZANOWSKI, F.C.; VIEIRA, R.D.; FRANÇA-NETO, J.B. (Ed.). Vigor de sementes: conceitos e testes. Londrina: ABRATES, 1999. cap.3, p.1-24.

PRIESTLEY, D.A.; LEOPOLD, A.C. Lipid changes during natural aging of soybean seeds. Physiologia Plantarum, v.59, p.467-470, 1983.

RE, R.; PELLEGRINI, N.; PROTEGGENTE, A.; PANNALA, A.; YANG, M.; RICE-EVANS, C. Antioxidant activity applying an improved ABTS radical cation decolorization assay. Free Radical Biology and Medicine, v.26, n.9/10, p.1231-1237, 1999.

SHAHIDI, F.; WANASUNDARA, P.K.J.P.D. Phenolic antioxidants. Critical Reviews in Food Science and Nutrition, v.32, n.1, p.67-103, 1992.
SINGLETON, V.L.; ROSSI, J.A. JR. Colorimetry of total phenolics with phosphomolybdic-phosphotungstic acid reagents. American Journal of Enology and Viticulture, v.16, n.3, p.144-58, 1965.

STEWART, R.R.C.; BEWLEY, J.D. Lipid peroxidation associated with accelerated aging of soybean axes. Plant Physiology, v.65, p.245-248, 1980. http://www.plantphysiol.org/content/65/2/245.full.pdf

TAIZ, L.; ZEIGER, E. Fisiologia vegetal. 3. ed. Tradução: E.R. SANTARÉM. Porto Alegre: Artmed, 2004. 613p.

WOISKI, R.G.; SALATINO, A. Analysis of propolis: some parameters and procedures for chemical quality. Journal of Apicultural Reserch, v.37, n.2, p.99-105, 1998. 